\title{
Perception Status of Nursing Department Students in Terms of Spirituality and Spiritual Care
}

\author{
Özlem Ovayolu ${ }^{a}$ Sümeyra Mihrap İlter ${ }^{b}$ Sibel Serçe ${ }^{a}$ Nimet Ovayoluc $^{c}$

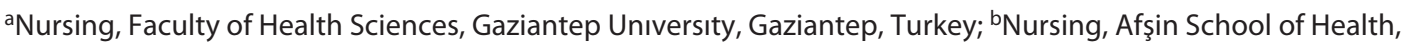 \\ Kahramanmaraş Sütçü Imam Unıversıty, Kahramanmaraş, Turkey; ` Nursing, Faculty of Health Sciences, Sanko \\ Unıversıty, Gaziantep, Turkey
}

\section{Keywords}

Spirituality $\cdot$ Spiritual care $\cdot$ Nursing $\cdot$ Education $\cdot$ Students

\begin{abstract}
Purpose: The study was conducted to examine the spirituality and spiritual care perceptions of nursing department students. Methods: The study was conducted in descriptive design with nursing students at a state university. Permission was obtained from the ethics committee, the institution, and the students before the study. The universe of the study consisted of all nursing students studying at the faculty, and the sample consisted of a total of 500 students who were willing to participate in the study. The data were collected with a questionnaire and with the Spirituality and Spiritual Care Detection Scale. The scores received from this scale were between 17 and 85, and high total scores suggest that the spirituality and spiritual care detection scale level is "good." The data obtained in the study were evaluated with the Student $t$, one-way ANOVA, and Mann-Whitney U test. Results: It was determined that $66.2 \%$ of the students had knowledge about spiritual care, $27.4 \%$ received this knowledge from the school, and $60.2 \%$ met the need for spiritual care with worshiping. It was determined that the mean spirituality and
\end{abstract}

karger@karger.com www.karger.com/dmj

Karger $\stackrel{\text { ' }}{5}$
(C) 2021 The Author(s)

Published by S. Karger AG, Basel

This is an Open Access article licensed under the Creative Commons Attribution-NonCommercial-4.0 International License (CC BY-NC) (http://www.karger.com/Services/OpenAccessLicense), applicable to the online version of the article only. Usage and distribution for commercial purposes requires written permission. spiritual care detection scale score of nursing students was $66.83 \pm 5.01$, and the mean spirituality and spiritual care detection scale score was statistically significant according to the grades $(p<0.05)$. It was also found that the students with an authoritarian family structure had lower mean spirituality and spiritual care detection scale scores than students with democratic and protective families. Conclusions and Recommendations: It was found that many nursing department students had knowledge on spirituality and spiritual care, the mean spirituality and spiritual care score was "good," and that the family structure and the grade affected this situation. In this respect, it is recommended that students are supported and prepared for the clinic with topics including spirituality and spiritual care in nursing education.

(c) 2021 The Author(s)

Published by S. Karger AG, Basel

\section{Introduction}

The philosophy of nursing is based on whole care concept. The individual in terms of whole care is an entity with physical, psychological, social, and spiritual dimensions that must be approached as a whole according to these dimensions in the delivery of health services $[1,2]$. 
The full well-being of the individual and improvement in the quality of life are possible by maintaining the integrity of these dimensions [1, 3-5]. The American Holistic Nurses Association (AHNA) defines good health as the level of agreement between the body, brain, and soul [4, 5]. The International Council of Nurses (ICN) states that protecting and improving health, preventing diseases, and alleviating pain are the main functions of a nurse. According to the ICN, nurses should provide holistic care to patients. Spirituality is one of the most important elements of holistic care $[2,3,5]$. Therefore, providing care for the spiritual dimension of the individual should be a part of a nurse's function as a universal point of view. For this reason, to maintain and preserve all of the dimensions and integrity of the individual's existence, nurses must be trained to provide care for all of these dimensions [4-6]. Spirituality according to Florence Nightingale: "Nurses are at the forefront of providing spiritual care compared to other health professionals." According to Joyce Travelbee, in 1971, "A nurse must not only alleviate physical problems of the individual, but also provide a holistic care to all the problems the individual gives"; she stated the importance of each dimension of maintenance including spirituality $[1,2,4,5]$.

The term "spirituality" is defined as the balancing of the adherence to a religion, energy, and basic trust in the nursing literature, and it is emphasized that providing spiritual care is the main duty of all nurses [7]. For this reason, spiritual care should be considered as a human requirement [7-10]. In the literature, it is stated that spirituality has important effects on health, well-being, and quality of life, and it is emphasized that it has an important role in the recovery of diseases $[8,10]$. It is also stated that spiritual care can often begin with a "compassionate approach" in human relations, and only such care can hear and recognize the needs of the human soul. It is reported that this unique support can also be provided either by giving belief support for the person to pray, to express himself/herself, or only as an active listener, especially in cases like traumas or diseases [11-14]. On the other hand, it is also stated that although spiritual care rests at the very center of nursing practices, its scope has not yet fully developed in the world and in our country $[2,5,13]$.

In nursing education, teaching spirituality-related information is seen as an opportunity to improve the quality of nursing care and to support the spiritual development and spiritual care skills of a student $[15,16]$. Also, including spirituality in nursing curricula contributes to the development of concepts like self, awareness, empa- thy, and sensitivity to spiritual needs in students [17-20]. For this reason, nursing students, who are preparing to become an important member of healthcare teams in the health system, should have sufficient knowledge about the knowledge and practices of nurses on spiritual needs and spiritual care $[9-11,19]$. This process ensures that the care provided to a patient is evaluated as a whole, and their spiritual needs are determined [18]. However, it is reported in the literature that students are not adequately equipped for spiritual needs throughout their nursing education, which negatively affects the quality of patient care given in clinics after graduation $[3,8,9,12]$. Inadequate provision of spiritual care may delay healing in the spiritual body and physiological body $[3,9,12]$. For this reason, this study targeted to evaluate the perception levels of nursing department students on spiritual support and the factors affecting this situation.

\section{Method}

Design, Setting, and Sample

The study was conducted in descriptive design with students of the Faculty of Health Sciences of a university. The university where the research was conducted is located in the southeast region of Turkey. The universe of the study consisted of 779 nursing students who received education at the faculty in the Spring Semester of 2019-2020 academic year. The study aimed to reach all the students of the nursing department in the health sciences faculty where the study was conducted, but the study was completed with 500 students at the school who agreed to participate in the study in the period when the data were collected.

\section{Collection of the Data}

After the necessary ethics committee and institution permissions were obtained, permission was obtained from the faculty member who was responsible for the course, and the purpose of the study was explained to the participants. In the classroom, information was given about the research by the researchers. Data collection forms were distributed, and they were asked to answer the targeted questions. The data were obtained with interviews with the students who accepted to participate in the study in the classrooms it would be held before the start of the course. Filling in the data collection tools was completed in a period of 10-15 min.

Data Collection Tools

The data were collected with a questionnaire and with the spirituality and spiritual care perception scale.

\section{The Questionnaire}

It consisted of questions that covered the characteristics of students to meet their sociodemographic and spiritual needs $[3,6,7]$.

Spirituality and Spiritual Care Detection Scale

The validity and reliability study of the Spirituality and Spiritual Care Detection Scale was conducted in Turkey by 
Table 1. The relationship between some characteristics of students and their perceptions of spirituality and spiritual care

\begin{tabular}{|c|c|c|c|c|}
\hline Feature & $N(\%)$ & $\mathrm{MMBA} X \pm \mathrm{SD}$ & $p$ value & $\begin{array}{l}\text { Test } \\
\text { volume }\end{array}$ \\
\hline \multicolumn{5}{|l|}{ Gender } \\
\hline Female & $385(77.0)$ & $66.67 \pm 4.90$ & \multirow{2}{*}{0.268} & \multirow{2}{*}{$1.109^{*}$} \\
\hline Male & $115(33.0)$ & $66.38 \pm 5.36$ & & \\
\hline \multicolumn{5}{|l|}{ Age } \\
\hline $18-21$ & $375(75.0)$ & $66.64 \pm 4.82$ & \multirow{3}{*}{0.201} & \multirow{3}{*}{$1.610^{*}$} \\
\hline $22-25$ & $115(23.0)$ & $67.29 \pm 5.60$ & & \\
\hline 25 and older & $10(2.0)$ & $68.90 \pm 4.67$ & & \\
\hline \multicolumn{5}{|l|}{ Undergraduate class } \\
\hline 1 & $116(23.2)$ & $65.02 \pm 5.30$ & \multirow{4}{*}{0.000} & \multirow{4}{*}{$9.329^{* *}$} \\
\hline 2 & $164(32.8)$ & $66.60 \pm 3.93$ & & \\
\hline 3 & $124(24.8)$ & $67.93 \pm 4.08$ & & \\
\hline 4 & $96(19.2)$ & $68.01 \pm 6.56$ & & \\
\hline \multicolumn{5}{|l|}{ What is the graduate high school? } \\
\hline Science high school & $37(7.4)$ & $66.59 \pm 4.94$ & \multirow{5}{*}{0.021} & \multirow{5}{*}{$2.910^{* *}$} \\
\hline Private high school & $42(8.4)$ & $69.00 \pm 4.52$ & & \\
\hline Anatolian high school & $386(77.2)$ & $66.76 \pm 4.94$ & & \\
\hline Health vocational high school & $19(3.8)$ & $65.10 \pm 6.87$ & & \\
\hline Religious high school & $16(3.2)$ & $65.43 \pm 4.56$ & & \\
\hline \multicolumn{5}{|c|}{ How would you describe your family } \\
\hline Democratic & $80(16.0)$ & $67.10 \pm 5.01$ & \multirow{3}{*}{0.005} & \multirow{3}{*}{$5.413^{* *}$} \\
\hline Authoritarian & $135(27.0)$ & $65.16 \pm 6.53$ & & \\
\hline Protector & $285(57.0)$ & $67.18 \pm 4.42$ & & \\
\hline \multicolumn{2}{|l|}{ SSCDS score average } & \multicolumn{3}{|c|}{$66.83 \pm 5.01(\min -\max : 17-85)$} \\
\hline
\end{tabular}

Ergül and Bayik Temel [21]. The scale, which included a total of 17 questions, consists of the subdimensions of spirituality and spiritual care, piety, and individual care. The scoring of the items is made starting from 1 , which bears the statement "I absolutely disagree," to 5, which carries the statement "I totally agree." The first 13 items were scored regularly, and the last 4 items [14-17] were scored reversely. The lowest score that can be obtained from the scale is 17 , and the highest score is 85 . The high overall score suggests that the perception of the concepts of spirituality and spiritual care is at a "good" level [21]. The scale reflects spirituality and spiritual care. It covers the general scope of the scale and does not include the subdimensions.

\section{Statistical Method}

The normality distribution of the data was evaluated with the Shapiro-Wilk test. Independent $t$ test was used in normally distributed independent groups. One-way ANOVA test was used to compare a numerical variable with 3 or more groups. The Mann-Whitney $\mathrm{U}$ test was used to compare 2 groups that did not show normal distribution.

\section{Findings}

Examining the Findings of the Relation between Sociodemographic Characteristics of Students and Mean SSCDS Score

It was found that a total of $77 \%$ of the students who participated in the study were female, $75 \%$ were in the $18-21$ age range, $32.8 \%$ were second-grade nursing students (academic grade), and 57\% had protective family structures. It was also found that the mean SSCDS score of the students who participated in the study was $66.83 \pm$ 5.01 , and a significant relation was detected between the grade and family structures of the students and the SSCDS scores $(p<0.05)$. However, although the mean SSCDS score for individuals over the age of 25 was higher, it was found that no statistically significant relations were detected $(p>0.05)$. The SSCDS average score of the students studying in private high schools was statistically higher $(p<0.05)$ (Table 1). 
Table 2. Comparison of students' knowledge of spiritual care and perception of spirituality and spiritual care average score

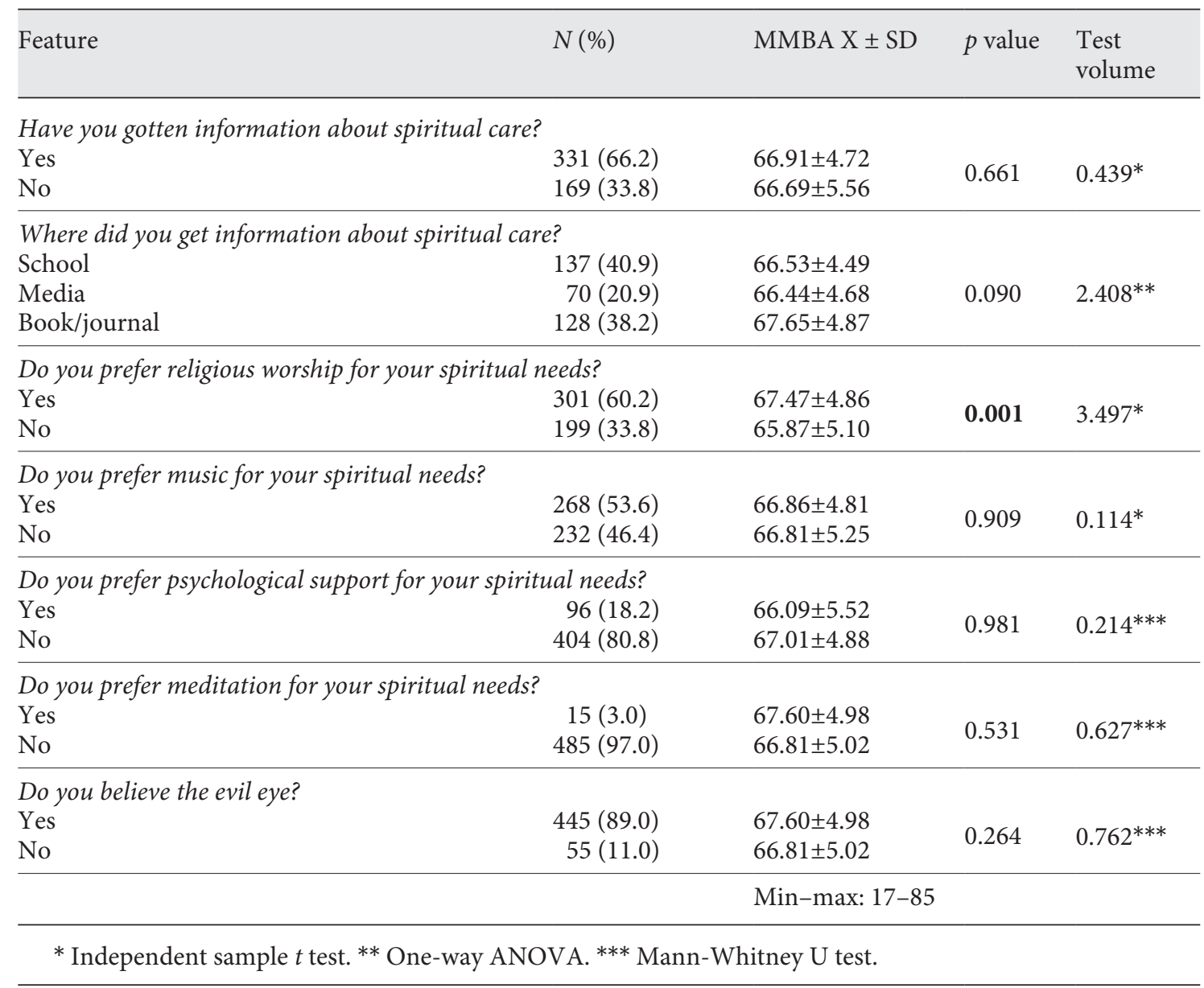

Examining the Findings of the Relation between the Knowledge of Spiritual Care and SSCDS Score Average of Students

It was found that $66.2 \%$ of the students received knowledge on spiritual care, $40.9 \%$ received this from the school, $89 \%$ believed in the evil eye concept, $60.2 \%$ worshiped to meet their spiritual needs, $53.6 \%$ listened to music, $18.2 \%$ received psychological support, and $3 \%$ meditated to meet their spiritual needs. It was also found that those who read books and magazines, meditated, and believed in evil eye to meet the requirements of spiritual care had high levels of perception of spirituality and spiritual care $(p>0.005)$. Also, those who met the requirements of spiritual care with worshiping had higher perception level in terms of spirituality and spiritual care, which was statistically significant $(p<0.05)$ (Table 2$)$.

Spirituality and Nursing

\section{Discussion}

A human being is a whole with all the concepts of body, mind, and soul. For this reason, every person needs to meet physical, social, mental, and spiritual needs in these areas $[1,2]$. However, although a materialistic approach to health and recovery is at the forefront in the accelerated technological development and scientific discovery environment of our present day, the role of spirituality has been considered less. For this reason, how much spiritual needs are met is a controversial issue. Of course, nursing is a professional group with an important place in spiritual care in the healthcare system $[19,20]$. However, the inability to provide sufficient education on spiritual care in the curricula may adversely affect patient results in clinical practice during the student years and also in clinics served after graduation $[4,5,11,22]$. For 
this reason, in order for spiritual care, which is one of the building blocks of holistic caretaking, to take part in nursing practices, it is important to have this understanding in theoretical and clinical applications. In this respect, the present study was planned to examine the level of perception and related factors regarding spirituality and spiritual care of nursing students. It was determined in this study that the mean scale score of the nursing department students for spiritual care was at a good level (66.83 \pm 5.01). Similarly, in the study conducted by Erenoğlu and Can [22] and Ince and Akhan [6], it was found that the perceptions of nursing department students on spiritual care were good; however, the mean scores in spiritual care were not sufficient in the study conducted by Bulut and Meral [3] and Yilmaz and Okyay [23]. The difference in terms of the results of this study might be related to the cultural structures, beliefs, and differences that stem from the nursing undergraduate education curricula. The difference in the time period allocated for spirituality education in different universities in nursing education explains the differences in the curriculum.

Family is a social unit that has biological, psychological, economic, social, and legal aspects with which the cultural and religious values of the society are transferred from generation to generation, but is also a character school where the individual monitors the first examples of behaviors, converting some of these behaviors seen in the family into habits [24]. Common family types include authoritarian, protective, and democratic family structures. Democratic family: unconditional love toward their children and also the family has an attitude of respect. Authoritarian family: parent attitude is called oppressive attitude, and the child's interest, needs, and expectations are not considered. Maintaining authority in the family is very important. The child is punished when he does not obey the authority. Protector family: this family includes situations where even what the child can do is restricted by the parents (not because of pressure or authority, but because they are worried about the child) [25]. Traditions in the possession of the parents may be affected by the moral values in their families. How parents express their parents' spiritual beliefs, the level of autonomy the individual has regarding these beliefs, what differences and similarities are in the parents' expression of beliefs, and the degree to which the parent maintains their parents' spiritual beliefs can affect their current spirituality. For this reason, the family structure affects the way the individual evaluates incidents [26]. In this study, the family structure was evaluated by the student's expression. In this study, a significant relation was detected be- tween the family structure and the mean score of the perception scale of spirituality and spiritual care, which was based on the authoritarian family structure $(p<0.05)$. Pour et al. [9] examined the perceptions of spiritual care of nursing and midwifery department students and found that students with authoritarian family structures had lower mean scores in spiritual care. In a study examining the relation between the family structure in which health sciences students grew up and the way they expressed in a moment of anger, it was found that the anger levels of students who described their family structure as oppressive and authoritarian were higher than those of other students [27]. In a systematic review that examined the effects of the behaviors of parents on the psychology of children, it was found that children who were raised in an authoritarian family structure had insufficient problemsolving skills than those who were raised in the democratic family structure [28]. However, a similar study conducted with university students found no significant relations between family structure and problem-solving skills [29]. All these results can be associated with individuals growing up in authoritarian family structures being more inclined to think concretely.

In the present study, it was found that more than half of the nursing department students had prior knowledge on spiritual care and received this knowledge outside the school with books, journals, and the media. In the study conducted by Sağkal Midilli et al. [16], it was found that nearly half of the nursing department students had knowledge on spiritual care and received this knowledge mostly from the faculty where they studied at; $62.7 \%$ of the nurses and midwives have heard the spiritual care concept in Kostak et al. [30] study; and in the study by Erenoglu and Can [22], more than half (58.8\%) of the nursing department students had knowledge on spiritual care.

The different cultural structures of the students affected the methods of meeting and applying spiritual care requirements. It was found in this study that most of the nursing department students met the need for spiritual care with worshiping, and a significant relation was detected between those who met the need for spiritual care by worshiping and those who met the need for spiritual care $(p<0.05)$. Pour et al. [9] examined the perception levels of students of spiritual care of nursing and midwifery department and found that the scale scores of spiritual care were at good levels in the religious subdimension. A similar study was conducted by Ince and Akhan Utaş [6] on nursing students, and they found that the mean religious subdimension score in spiritual care was good [9]. 
Evil eye is often expressed as the "effect of the look" in our culture; however, it is widely stated as the energy it carries in the "looker" and the expression of this energy. It is also defined as the material and spiritual effect the looks have on people, animals, plants, and things they look at [31]. In this study, no significant relations were detected between evil eye and mean SSCDS score; however, the majority of the students who participated in the study $(89.0 \%)$ believed in evil eye. This result suggests that it is common to believe in evil eye in the geographical area in which the study was conducted and may be associated with the cultural characteristics of the students.

\section{Result and Recommendations}

It was determined that the mean SSCDS score of the nursing students was at a good level, their grade and family structure affected the perception level of spiritual support, and the students mostly worshiped to meet their spiritual needs. In line with these data, it is recommended that the perspective of nursing department students on the concept of spirituality and the factors affecting them are evaluated to provide students with up-to-date and complete knowledge by integrating these with nursing education.

\section{Limitations of the Study}

The most important limitation of this study was that the levels of spirituality and spiritual care perception of nursing department students were evaluated only with scales.

\section{Acknowledgments}

The authors wish to acknowledge the contribution of nursing students at Gaziantep University during phases of the study.

\section{Statement of Ethics}

The Ethics Committee of Gaziantep University approved this study (23.10.2019/380). Permission was obtained from the Gaziantep University Faculty of Health Sciences Nursing Department for conducting this study. Written and verbal consent was obtained from the participants. All authors acknowledge that this research was conducted in accordance with the Declaration of Helsinki.

\section{Conflict of Interest Statement}

The authors declare no conflicts of interest; this article does not concern any commercial product.

\section{Funding Sources}

This study was not funded by any organization.

\section{Author Contributions}

Ö.O. and S.M.İ. designed the work. S.S. and N.O. collected the data. O.O. and S.M.I. contributed to the statistical analysis.

\section{Data Availability Statement}

All data generated or analyzed during this study are included in this article. Further enquiries can be directed to the corresponding author.

\section{References}

1 Dağhan Ş. Nursing students' perceptions of spirituality and spiritual care; an example of Turkey. J Relig Health. 2018;57(1):420-30.

2 Booth L, Kaylor S. Teaching spiritual care within nursing education: a holistic approach. Holist Nurs Pract. 2018;32(4):177-81.

3 KobyaBulutH,MeralB.ÖğrenciHemşirelerin Maneviyat ve Manevi Bakımı Algılama Düzeyleri ve Etkileyen Bazı Faktörlerin Belirlenmesi. Gümüşhane Üniversitesi Sağlık Bilimleri Dergisi. 2019;8(4):353-62.

4 Ergül Ş, Bayık A. Hemşirelik ve manevi bakım. Cumhuriyet Üniversitesi Hemşirelik Yüksekokulu Dergisi. 2004;8(1):37-45.

5 Govier I. Spiritual care in nursing: a systematic approach. Nurs Stand. 2000;14(17):32-6.
6 Çelik İS, Akhan Utaş L. Öğrenci Hemşirelerin Maneviyat ve Manevi Bakıma İlișkin Algıları. Hemşirelikte Eğitim Ve Araştırma Dergisi. 2016;13(3):202-8.

7 Kavak F, Mankan T, Polat H, Sarıtaş SÇ, Sarıtaș S. Hemşirelerin Manevi Bakıma İliş̧kin Görüşleri. İnönü Üniversitesi Sağlık Bilimleri Dergisi. 2014;3(1):21-4.

8 Gönenç IM, Akkuzu G, Altın RD, Möroy P. Hemşirelerin ve ebelerin manevi bakıma ilişkin görüşleri. Gümüşhane Üniversitesi Sağlik Bilimleri Dergisi. 2016;5(3):34-8.

9 Pour Asgar H, Özvurmaz S, Kunter D. Hemşirelik ve Ebelik İntörn Öğrencilerinde Manevi Bakıma Yönelik Algı ve Uygulama Modelinin Değerlendirilmesi. J Contemp Med. 2017;7(3):225-33.
10 Coyle J. Spirituality and health: towards a framework for exploring the relationship between spirituality and health. J Adv Nurs. 2002;37(6):589-97.

11 Herlianita R, Yen M, Chen CH, Fetzer SJ, Lin EC. Perception of spirituality and spiritual care among Muslim nurses in Indonesia. J Relig Health. 2018;57(2):762-73.

12 Tirgari B, Iranmanesh S, Cheraghi MA, Arefi A. Meaning of spiritual care: Iranian nurses' experiences. Holistic Nursing Practice. 2013; 27(4):199-206. 
13 Ross L, McSherry W, Giske T, Van Leeuwen R, SchepAkkerman A, Koslander T, et al. Nursing and midwifery students' perceptions of spirituality, spiritual care, and spiritual care competency: a prospective, longitudinal, correlational Europeanstudy. Nurse Educ Today. 2018;67:64-71.

14 Selman LE, Brighton LJ, Sinclair S, Karvinen I, Egan R. Speck P, et al. Patients' and caregivers' needs, experiences, preferences and research priorities in spiritual care: a focus group study across nine countries. Palliat Med. 2018;32(1):216-30.

15 Caldeira S, Simões Figueiredo A, da Conceição A, Ermel C, Mendes J, Chaves E, et al. Spirituality in the undergraduate curricula of nursing schools in Portugal and São PauloBrazil. Religions. 2016;7(11):134-9.

16 Sağkal Midilli T, Kalkım A, Dağhan S. Hemşirelik öğrencilerinin manevi bakıma ilişkin görüş ve uygulamaları. J Hum Sci. 2017;14(1):666-77.

17 Baldacchino DR. Teaching on the spiritual dimension in care: the perceived impact on undergraduate nursing students. Nurse Educ Today. 2008;28:501-12.
18 Aştı TA, Karadağ A. Hemşirelik Esasları: Hemşirelik Bilimi ve Sanatı 2: Akademi Basın Yayıncilık, İstanbul, sy; 2013. p. 1134-44.

19 Narayanasamy A, Owens J. A critical incident study of nurses' responses to the spiritual needs of their patients. J Adv Nurs. 2001; 33(4):446-55.

20 Govier I. Spiritual care in nursing: a systematic approach. Nurs Stand. 2000;14(17):32-6.

21 Ergül S, Temel A. B "Maneviyat Ve Manevi Bakım Dereceleme Ölçeği”nin Türkçe Formunun Geçerlilik Ve Güvenilirliği. Ege Üniversitesi Hemşirelik Yüksekokulu Dergisi. 2007;23(1):5-87.

22 Erenoğlu R, Can R, Spiritual support perceptions and the affecting factors of students among nursing school. JAREN. 2019;5(1):2330.

23 Yilmaz M, Okyay N. Hemșirelerin maneviyat ve manevi bakıma ilişkin görüşleri. Hemşirelikte Araştırma Geliștirme Dergisi. 2009;11(3):41-51.

24 Özkan F. Ailenin Dini Tutum ve Davranışlarının Çocuğun Dini Tutum ve Davranışlarına Etkisi: Diyarbakır Örneği. Mîzânü’l-Hak İslami İlimler Dergisi. 2018;7: 63-109.

25 Bilecik S. Anne Baba Tutumlarının Bireylerin Din Algisına Etkisi. Değerler Eğitimi Dergisi. 2017;15(33):7-38.
26 Tunç B, Totan T. Aile Yaşamında Maneviyat: Aile Psikolojik Danışmasında Maneviyatın Değerlendirilmesi. Dumlupınar Üniversitesi Eğitim Bilimleri Enstitüsü Dergisi. 2021;5(1): $1-20$.

27 ElkinN,KaradağlıF.ÜniversiteÖğrencilerinin Öfke İfade Tarzı ve İlişkili Faktörler. Anadolu Kliniği. 2016;21(1):64-71.

28 Sümer N, Aktürk Gündoğdu E, Helvac1 E,Anne-Baba Tutum ve Davranışlarının Psikolojik Etkileri: Türkiye'de Yapılan Çalışmalara Toplu Bakış, Türk Psikoloji Yazıları, Haziran 2010, 13 (25), 42-59.

29 Güngör M. Üniversite öğrencilerinin problem çözme becerilerinin aile tipleri ve aile tutumları açısından incelenmesi. E J New World Sci Acad. 2012;7(4):40-51.

30 Kostak MA, Çelikkalp Ü, Demir M. Hemşire ve ebelerin maneviyat ve manevi bakıma ilişkin düşünceleri. Maltepe Üniversitesi Hemșirelik Bilim ve Sanatı Dergisi. 2010; (Sempozyum Özel Sayıs1):218-25.

31 Ekici M, Fedakar P. Gelenek, Aktarma, Dönüşüm Ve Kültür Endüstrisi Bağlamında Nazar Ve Nazar Boncuğu. Millî Folklor. 2014; 26(101):44-50. 